\title{
BÓG W POEZJI STANISŁAWA BARAŃCZAKA - REŻYSER LOSU I ŚWIADEK ISTNIENIA
}

\section{Joanna KOSTUREK (Kraków)}

Bóg w poezji Stanisława Barańczaka pozostaje Bytem Nieodgadnionym, którego istotę człowiek wciąż próbuje rozszyfrować. Najważniejszą kwestią dotyczącą Stwórcy staje się zaś ta, która dotyczy samego człowieka - pytanie o faktyczność i sposób uczestnictwa Boga w cierpieniu, a także — szerzej: w ludzkim Losie ${ }^{1}$.

W tytułowym wierszu tomu Widokówka z tego świata zakłada się, że chociaż boskie Ty przekracza dostępne ludziom odczucie przestrzeni i czasu, to w jakiś sposób może poznać ból ograniczonego w swym bycie człowieka. Ostatnie pytanie w utworze brzmi przecież: , j a k boli” (W*, s. 362) — nie zaś: „, c z y boli” [podkr. moje - J.K.]. W wierszu Prześwietlenie, pochodzącym z tego samego tomu, Bóg nazwany zostaje natomiast Radiologiem Bez Twarzy — Jego cechą jest bowiem ,prześwietlanie duszy”"2:

* Przy każdym cytowanym fragmencie wiersza podany jest skrót tomu, z którego utwór pochodzi, oraz strona, na której można ów fragment znaleźć w zbiorze: S. Barańczak, Wiersze zebrane, Kraków 2007; T - Tryptyk z betonu, zmęczenia i śniegu (1980); A - Atlantyda (1986), W — Widokówka z tego świata (1988), PZ — Podróż zimowa (1994), ChP — Chirurgiczna precyzja (1998).

${ }^{1}$ Zapis tej kategorii wielką literą wydaje się w przypadku poezji Barańczaka uzasadniony wyłania się z niej bowiem spójna koncepcja biegu ludzkiego życia. W całym chaosie, przypadkowości i nieprzewidywalności istnienia są punkty stałe, niezmienne wytyczne Losu — są nimi cierpienie i śmierć. W licznych wierszach pojawia się — idący śladem ojcowskiego głosu z wiersza Czerwiec 1962 - pesymistyczny obraz ludzkiego Losu, wizja człowieka jako istoty podległej prawom biologii, istoty, która „pozwana jest na proces gnilny”, a ponadto cierpi, jest krucha, tymczasowa, zagrożona wciąż nicością.

2 Określenie K. Biedrzyckiego, „Drogi kąciku porad” Stanisława Barańczaka. Wariacje metafizyczne, [w:] Lektury polonistyczne. Literatura wspótczesna, red. R. Nycz, J. Jarzębski, t. 1, Kraków 1997, s. 400. 


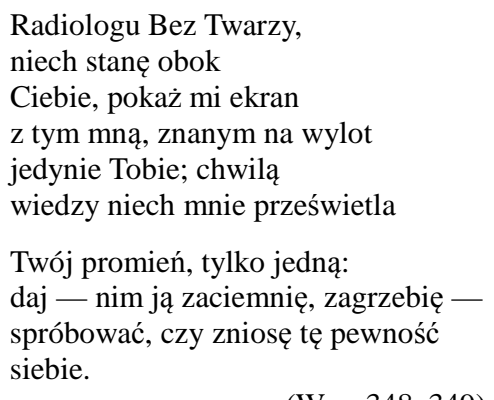

$$
\text { (W, s. 348-349) }
$$

Bóg uczestniczyłby zatem w Losie człowieka przez znajomość jego kondycji — tej kondycji, która w utworach takich, jak Cape Cod i cytowany tu wiersz Prześwietlenie jawi się jako wewnętrzne skomplikowanie, odczucie przez człowieka absurdu istnienia i własnej obcości w świecie. Boska wiedza jest tu absolutna i jako taka okazuje się wiedzą przewyższającą nawet człowiecze zdolności czytania własnej egzystencji. Bóg-Radiolog Bez Twarzy wyjawia przecież podmiotowi jakąś ostateczną wiedzę o nim samym, prawdę, którą bohater lęka się poznać. Wiedza ta nie jest jednak tożsama ze współczuciem.

W wierszu Msza za Polskę w St. Paul's Church, grudzień 1984 z tomu Atlantyda czytamy o rytuale mszy odprawianej w intencji ojczyzny, a zatem mszy w trakcie której wierni proszą Stwórcę o pomoc i wstawiennictwo w odzyskaniu niezależności kraju. Rytuał ten jednak wcale nie umożliwia kontaktu z Bogiem, nie prowadzi ku sacrum - w trakcie jego trwania odbierane są przecież tylko uchwytne zmysłowo zjawiska, które dzieją się we wnętrzu kościoła: zachowanie i wygląd ludzi, podmuch wiatru, dźwięki. A zatem — jak należy sądzić — msza nie staje się również formą, za pośrednictwem której Bóg mógłby uczestniczyć w ludzkim Losie ${ }^{3}$ (w tym przypadku: udzielić człowiekowi pomocy w doświadczanym przez niego zniewoleniu).

$\mathrm{W}$ trzech wersach pisanych kursywą (każdy z nich kończy jedną ze strof) pojawia się jednak również obraz cierpiącego Chrystusa: dtonie przebite ćwiekami (A, s. 293), głowa w cierniach (A, s. 293), wołanie znad belki krzyża (A, s. 294). Przywołuje się więc postać Boga-człowieka, ucieleśnionego, cierpiącego i konającego. Między takim Bogiem a człowiekiem budowana jest paralela: za plecami zwiazane dtonie (A, s. 293), pałkami zmasakrowana głowa (A, s. 293), uderzenia w bagażnik fiata (A, s. 294). Ten cierpiący i brutalnie zabijany człowiek to ksiądz Jerzy Popiełuszko, którego śmierć zestawioną z męczeństwem Zbawiciela - także można pojmować jako formę ofiary „za sprawę”. Zarysowywałaby się tu zatem wspólnota przeżyć obywatela państwa (państwa, w intencji którego jest odprawiana msza) i Boga-człowieka, który przez doświadczenie śmierci i cierpienia uczestniczy w ludzkim Losie w sposób pełny.

W wierszu kwestia ta jednak nie jest jednoznacznie rozstrzygnięta. Pojawia się tu bowiem pytanie: czy mimo wspólnoty tych „granicznych” doświadczeń rzeczywistość ludzka nie pozostaje jednak przestrzenią obcą Bogu? ${ }^{4}$ Bo przecież ludzka śmierć i ludz-

\footnotetext{
${ }^{3}$ Por. odczytanie tego wiersza przez J. Kandziorę, Ocalony w gmachu wiersza. Człowiek wobec Historii w „Atlantydzie” Stanistawa Barańczaka, Pamiętnik Literacki 2005 z. 3, s. 172, 173-176.

${ }^{4}$ Zdaniem Dariusza Pawelca pytanie „o zależność codziennych ludzkich spraw od cierpienia Chrystusa jest pytaniem o to, czy Bóg istnieje” (D. Pawelec, Poezja Stanisława Barańczaka. Reguty i konteksty, Katowice 1992, s. 167). Krzysztof Biedrzycki pisze zaś o różnicy doświadczeń egzystencjalnych, wątpliwości ,,co do możliwości bycia w pełni solidarnym z owym hero-
} 
kie cierpienie nie zawsze dokonują się w imię wartości wyższych, uzasadniającego je jakoś sensu, bo przecież przepełniający ludzkie istnienie ból (zarówno fizyczny, jak i będący wynikiem doświadczeń duchowych) jest prozaiczny, nieustanny, przybiera wręcz formę codziennego trudu:

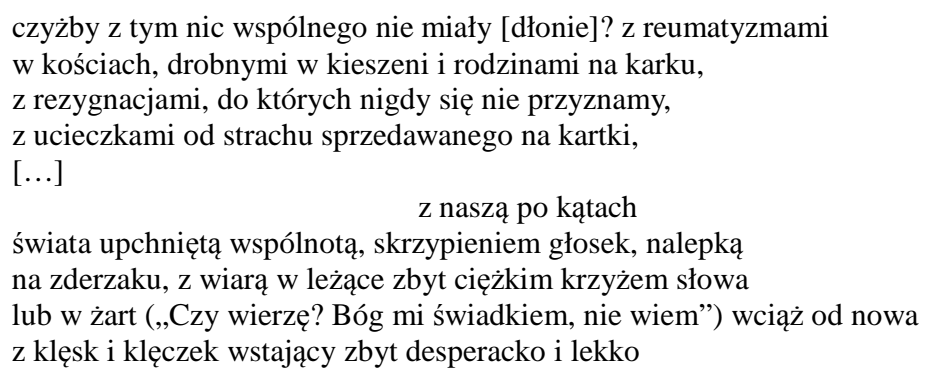

(A, s. 293)

W strofie ostatniej dokonuje się swoista „zamiana” wzniosłego hymnu do Boga o męce Ojczyzny ${ }^{5}$ na hymn ,żywego ciała” (A, s. 294). Wzniosłe (i jednak bardziej boskie niż ludzkie) cierpienie-ofiara oraz poświęcenie ,za sprawę” zamienione zostają na doświadczenie cierpienia ,zwykłego", somatycznego ${ }^{6}$ :

[...] Otwieramy śpiewniki na hymnie żywego ciała, numer nieskończony, na jego treści żołądkowej, śluzówce, nerwach wrażliwych na zimno i ból $[\ldots]$

$$
\text { (A, s. 294) }
$$

Ów „hymn” jest właśnie prawdziwym „tekstem” o istnieniu człowieka, którego odczytanie jest zadaniem dla Boga, zadaniem, którego wypełnienie umożliwiłoby $\mathrm{Mu}$ dopiero uczestniczenie w ludzkim Losie. Tak więc to nie człowiek ma czytać kod sacrum, jakim w wierszu był „martwy” i obcy rytuał mszy, lecz Bóg uczestniczyć ma w ,rytuale człowieczeństwa”:

$$
\begin{aligned}
& \text { czy to obejmie [głowa w cierniach - J.K.], czy się to w niej mieści? } \\
& \text { [...] } \\
& \text { tylko takimi możesz nas objąć, pojąć i mieć, }
\end{aligned}
$$

icznym poświęceniem” (K. Biedrzycki, Świat poezji Stanisława Barańczaka, Kraków 1995, s. 58), które staje się „kontrapunktem dla przeżyć emigranta” (tamże).

5 Jest to hymn — jak mówi się w strofie pierwszej — trzydziesty ósmy, jego słowa zaś przytoczone zostają w strofie drugiej - i to nie w celu zamieszczenia jakiejś wzniosłej refleksji na temat męczeństwa Polski (tradycyjnie przez Polaków postrzeganego jako wzniosły) - lecz dodania uszczypliwej uwagi o wątpliwym kunszcie pieśni: „«Jak długo męka twa trwa,/ Ojczyzno», przy bocznym ołtarzu emigracyjny kontralt,/ «twa - trwa»! powinno się dawać mandat za takie dwa/ zaparkowane zbyt blisko słowa" (A, s. 293).

${ }^{6}$ Jerzy Kandziora widzi w tych wersach nie tyle zamianę, ile ,u to żs a mi e n i e tekstu sakralnego, nieskalanej konkretem ciała stronicy jakiegoś śpiewnika kościelnego, z dramatycznie przywołaną treścią żołądkową [...]”; J. Kandziora, Ocalony w gmachu wiersza, s. 174. Słowo „treść" ewokuje także - zdaniem badacza — protokół sekcji zwłok. W interpretacji Jerzego Kandziory potencjał metaforyczny tego słowa i jego homonimiczność umożliwiają spotkanie się, zjednoczenie dwóch wymiarów - cielesności i sacrum. Tym samym poetyckie słowo staje się „,doskonałym nośnikiem tran s cende n cji w tym najbardziej etymologicznym znaczeniu przekraczania (łac. transcendere) wymiarów”; tamże. 


\begin{abstract}
ze wszystkim, ze zdrętwiałym kolanem, spłowiałą chorągwią, nielogiczną miłością do tych, a nie innych miejsc, twarzy, skrzypiących dźwięków; z nieuleczalną chorobą nadziei
\end{abstract}

(A, s. 294)

Problem cierpienia oraz zła (co istotne — także moralnego) zajmuje również bohatera wiersza Drogi kąciku porad. Człowiek pragnie tu znaleźć sposób, który pomógłby mu znieść ogrom nieszczęść spotykających ludzkość: „akt terroru”, „trupy dzieci”, „dym z ruin”, „kościsty głód” (W, s. 376). Krzysztof Biedrzycki uznaje, że poszukiwania te motywowane są pragnieniami mieszkańca „bogatego, ustabilizowanego świata”, który jest bezradny wobec zła, chce wieść spokojne, niefrasobliwe życie ${ }^{8}$. Uzasadnienia tych poszukiwań — „wpadam wciąż w depresję, widząc/ krew” (W, s. 376), „W rezultacie dręczy mnie, niestety,/ bezsenność” (W, s. 376), ,proszę o pomoc, bo tracę apetyt” (W, s. 376), „Nie mogę jeść, gdy znów na zdjęciu człowiek/ irracjonalnie zdycha” (W, s. 376) - można jednak odczytać również jako świadectwo maksymalnego udręczenia bohatera przez świadomość zła - udręczenia uniemożliwiającego wykonywanie podstawowych czynności fizjologicznych, a więc uniemożliwiającego dalszą egzystencję.

Słowa skierowane przez bohatera wiersza do boskiego Ty nie są bezpośrednim pytaniem o przyczyny i sens zła. Są natomiast pytaniem o istnienie Boga i prośbą o ujawnienie znaków Jego obecności w świecie. Należy więc uznać, że obecność ta byłaby dla pytającego ulgą w cierpieniu. Okazuje się, że Bóg istnieje (,JESTEM”, W, s. 377), ale w sposób nie przynoszący człowiekowi ratunku — „NIE MA MNIE PRZY TOBIE, / BO JESTEM/ WSZĘDZIE” (W, s. 377). Jeśli więc Bóg śledzi istnienie ludzi (co wcale nie jest w wierszu pewne, bo mówi się o tym słowami człowieka opatrzonymi znakiem zapytania), czyni to $\mathrm{z}$ odległości tak wielkiej, że nie zaspokaja to ludzkiej potrzeby współbycia i opieki ze strony Stwórcy ${ }^{9}$. Człowiek, widziany przez Boga z perspektywy wszechświata, z nieustannie wirującej przestrzeni kosmicznej, jest tylko „okruchem snu”, a więc nierealną drobiną, poruszającą się samotnie bez boskiego kierownictwa. Rolą Stwórcy byłoby tu jedynie pierwsze poruszenie (,wprawienie w obieg”) tej maleńkiej cząstki. Tym samym istota ludzka pozostaje w swej drodze-życiu samotna.

„Pakowną porcją” boskiej wiedzy o zbrodniach i grozie świata staje się w jednym z wierszy gazeta, po którą schyla się podmiot liryczny. Wiedza Stwórcy przekracza nawet człowiecze wyobrażenia o ogromie nieszczęść, których doświadcza ludzkość. Podmiot liryczny wyznaje więc Bogu:

\begin{abstract}
Nie myśl, że nie doceniam tego, że łagodnie oszczędzasz mnie, że nie chcesz mnie oniemić wszystkim, że to jedynie okruch grozy, zbrodnie ledwie niektóre z tych, o jakich Ci wiadomo
\end{abstract}

(Podnoszac z progu niedzielna gazetę, W, s. 343)

Słowa te nie są jednak pozbawione ironii i żalu — bo przecież tylko z bożej perspektywy zaznane przez człowieka w ciągu życia zło może być pojmowane jako nie-

\footnotetext{
${ }^{7}$ K. Biedrzycki, Świat poezji, s. 56.

${ }^{8}$ Zob.: tamże, s. 56, 251. We wnikliwej analizie wiersza Krzysztof Biedrzycki określa jednak bohatera utworu również jako człowieka poszukującego sensu odpowiedzi na najważniejsze egzystencjalne, metafizyczne pytania; K. Biedrzycki, „Drogi kąciku porad”, s. 418-421.

${ }^{9}$ Por.: tamże, s. 416.
} 
znaczna część całego „mroku”. Z perspektywy ludzkiej owo życie obarczone cierpieniem i grzechem jest przecież wszystkim, co zostało dane - doświadczany indywidualnie „okruch grozy” z takiej perspektywy to właśnie „ogrom”. Człowiecze o d c z u c i e zła przeciwstawione zostało więc bożej wiedzy na temat zła. Bo chociaż Stwórca ogarnia cały mrok — jest to tylko świadomość mroku, a nie jego doświadczanie. Ów nie-czuły Bóg, dla którego ludzka perspektywa jest czymś nieznanym, znajduje się poza światem, na którym szerzy się cierpienie i dokonuje się zbrodni — jest „wyniesiony nad sfery nieba” (W, s. 343). Człowiek podejrzewa jednak, że to On właśnie tworzy mrok: „Przyznaj się, tylko nie kręć, tylko nie milcz:/ tam, skąd patrzysz, drukuje się takie gazety" (W, s. 343). Przestrzeń boska okazywałaby się zatem miejscem, w którym układa się ,tekst” ludzkiego — pełnego śmierci i cierpienia — Losu ${ }^{10}$. Przerażającym darem Boga dla człowieka byłoby zaś „,pękate nasiono” (W, s. 343) przeznaczony dla każdego fragment mroku, zalążek zła, nieszczęścia, które przybierze konkretną postać, realizując się w biografii jednostki.

Motyw złego Boga zostaje rozwinięty w wierszu „Bist Du bei mir” zamieszczonym w ostatnim tomie poety. Cały utwór wzięty został w cudzysłów, stanowić ma zatem przytoczenie słów boskiego Bytu. Wypowiedź Boga jest odpowiedzią na słowa $\mathrm{z}$ arii Bacha, w których mowa o spokojnym — bo przepełnionym obecnością jakiegoś troskliwego i kochającego „ty” — oczekiwaniu na śmierć. Na człowiecze wezwanie bist Du bei mir (,bądź przy mnie”) odpowiada Barańczakowy Bohater zapewnieniem o swej ciągłej obecności: „«Przy tobie? Stale. Wiesz przecież. Od rana/ do następnego rana, licząc przerwę/ na noc»” (ChP, s. 459). Jego obecność jest jednak zaprzeczeniem tej, której oczekuje istota ludzka $\mathrm{z}$ arii $\mathrm{Bacha}^{11}$ :

$$
\begin{aligned}
& \text { „[...] ja rzucam wam tę samą linę } \\
& \text { ratunku albo powróz mąk do rana; } \\
& \text { z ukrycia, ale cały twój czas nami } \\
& \text { dwoma wypełniam, teraz, przedtem, potem. } \\
& \text { Twoje zuchwałe «Pozwól, że Ci przerwę», } \\
& \text { suflerskie przerwy, poprawki — nie przerwę } \\
& \text { wymuszą, tylko popsują rytm sceny; } \\
& \text { tekst pozostanie bez zmian. Zlany potem, } \\
& \text { ciągnij sznur dzwonu, opuszczaj w grób linę, } \\
& \text { dociskaj węzeł powroza i snami- } \\
& \text {-sznurkami dawaj się targać do rana, } \\
& \text { lecz wiedz: nie przerwę gry — linijki linę } \\
& \text { zawsze zza sceny podrzucę ci - snami } \\
& \text { stłumię ból — potem, gdy rwać zacznie rana” }
\end{aligned}
$$

(ChP, s. 460)

\footnotetext{
${ }^{10}$ Motyw Boga — złego, nieudolnego Stwórcy — pojawia się także w wierszach Yard sale, Czas skończyć z takimi, Chęci. O wątkach gnostyckich w Chirurgicznej precyzji Barańczaka: I. Misiak, Stanisława Barańczaka dialog chirurga i demiurga, Teksty Drugie 2007 nr 3, s. 8389; w Tryptyku z betonu, zmęczenia i śniegu: A. van Nieukerken, Stanisław Barańczak jako wspótczesny poeta metafizyczny, [w:] tegoż, Ironiczny konceptyzm. Nowoczesna polska poezja metafizyczna, Kraków 1998, s. 316-324.

${ }^{11}$ Por. uwagi J. Kandziory, Między wyobraźnia traumatyczna i geometryczną. Filozoficzne przestrzenie „Chirurgicznej precyzji” Stanistawa Barańczaka, cz. 1, Pamiętnik Literacki 2003 z. 2 , s. 135 .
} 
Istota ludzka okazuje się kukiełką, wykonującą jedynie ruchy, jakich żąda Bóg-Reżyser, niezdolną do zmiany odgrywanego „tekstu”, a zatem całkowicie zdeterminowaną i pozbawioną podmiotowości. Warto zauważyć, że w wierszach z tomu Widokówka z tego świata mówił człowiek, który — chociaż nie mógł poznać Boga — mógł kierować Doń pytania i tworzyć własne Jego wyobrażenia, układać (przynajmniej w sferze myśli) swój własny tekst (np. w utworach takich, jak Yard sale, Długowieczność oprawców, Ustawienie głosu). W utworze z Chirurgicznej precyzji poruszana przez Boga „lina”, na której zawieszony jest człowiek-kukiełka, to równocześnie „linijka” tekstu, według którego toczy się akcja ludzkiej gry-życia, a więc „tekst” ludzkiego Losu. Bóg okazuje się tu zatem fundatorem Losu budzącego lęk - scenariusza istnienia, w którym człowiek zmierza nieuchronnie do śmierci rozpięty między daremną nadzieją a rozpaczą, doświadczając cierpienia. Przestrzeń metafizyki w analizowanym wierszu okazywałaby się zatem miejscem, w którym powstaje projekt ciemnego Losu — przestrzenią wcale niestanowiącą owego „Więcej”, o którym mowa w pieśni VII z Podróży zimowej, niegwarantującą spełnienia obietnicy przekroczenia cielesnych ograniczeń, lecz rzeczywistością swoiście złączoną, sprzymierzoną ze światem śmierci i cierpienia.

Przy czym zły świat nie jest wynikiem Bożej nieudolności (Stwórca jest tu bytem wszechmocnym), a Los ludzki nie jest karą. Bóg staje się tu zatem złym demonem, którego obecność jest przekleństwem. Znamienne jest przyrównanie człowieka do ćmy, która pragnie światła poranka, oznaczającego wybawienie, koniec męki: ,potem// spływając - leżysz i razem z trzepotem/ ćmy o okienną siatkę czekasz rana” (ChP, s. 459). Istota ludzka przerażona jest skazaniem jej prze z B o ga na uwięzienie w „mroku” cierpienia i śmierci, trwaniem pośród takiej „metafizycznej nocy”. Jest także ślepa — po omacku i nieustannie pragnie wydostać się ze swego więzienia, nieświadoma jak i dlaczego się w nim znalazła. W utworze wyraźnie mówi się o owym niezrozumieniu przez człowieka sensu takiego istnienia: „,sceny,/ która się tobie wydaje obrana/ na chybił trafił z sensu" (ChP, s. 459). Człowiek w wierszu nie pojmuje motywów postępowania Boga. Ów sens — jeśli nawet istnieje — z ludzkiej perspektywy jest bezsensem, czymś demonicznym. Narzucony zostaje bowiem z góry, a nie kształtuje się indywidualnie w czasie niepowtarzalnego życia. W Widokówce z tego świata ważna była indywidualna biografia podmiotu lirycznego, wyłaniająca się z wierszy takich, jak Lipiec 1952, Czerwiec 1962, Wrzesień 1967, Grudzień 1976, Sierpień 1988. Przez interpretację zdarzeń dokonywaną przez podmiot liryczny, prowadząca do nadawania tym wydarzeniom sensów, kształtowała się jednostkowa prawda życia ${ }^{12}$. W „,Bist Du bei mir" biografia nie jest już indywidualnym konstruowaniem sensów przez jednostkę, lecz bezosobowymi więzami narzuconymi przez Boga, jednostajnym mijaniem czasu: „więzy to także więź, co spaja sceny, / aż stają się zimami i wiosnami” (ChP, s. 459). To, co poszczególne, intymne okazuje się tu wyłącznie powielaną przez Niego kopią: ,czyjś nowy sen skopiowanymi snami / zaludnić” (ChP, s. 459) ${ }^{13}$.

Opisana w wierszu możliwość relacji człowiek - Bóg jest chyba dla istoty ludzkiej równie wroga (może nawet bardziej?) jak ewentualność nieistnienia boskiego Ty.

\footnotetext{
12 Marian Stala pisał o układaniu się owych miesięcy „w zapis jednego losu, który trzeba zrozumieć, obdarzyć sensem"; M. Stala, Między tym światem a światem łaski, [w:] tegoż, Chwile pewności, Kraków 1991, s. 187.

${ }^{13}$ Por. wnikliwą interpretację tego utworu: J. Kandziora, Między wyobraźnią traumatyczną, s. 135-140. W swej interpretacji Jerzy Kandziora przeprowadza interesującą analizę przebiegu i konstrukcji rymów w utworze, skupiając się na sytuacji osaczania, zamknięcia, zdominowania istoty ludzkiej przez Boga, który arbitralnie ustala, zmienia sensy, nie dopuszcza do głosu i z którym człowiek jest połączony relacją zawdzięczania oraz utraty podmiotowości.
} 
Możliwość taka pojawia się w wierszach Barańczaka, między innymi jako topos pustego nieba. W Drogim kaciku porad niebiosa określone zostają mianem ,pustkowie”. W utworze Problem nadawcy czytamy natomiast o „Oku Niebytu” — wyrażenie to ewokuje dwa przeciwstawne wyobrażenia Boga. Oko kojarzy się bowiem z Okiem Opatrzności, a zatem Stwórcą otaczającym istoty ludzkie pełną opieką, Niebyt oznacza zaś nieistnienie nie tylko takiego — dobrego i troskliwego — Boga, lecz jakiegokolwiek boskiego Ty. W Widokówce z tego świata mowa o „mroźnej próżni”, w Wynoszac przed dom kubły ze śmieciami o „skraju pustki”. W wierszu Grudzień 1976 motyw ten zyskuje postać najbardziej chyba dramatyczną: okazuje się, że ludzkie skargi i protesty nigdzie nie docierają, że człowiek jest absolutnie samotny na Ziemi przykrytej „martwym kloszem ciszy".

W świecie nie można przecież odnaleźć jednoznacznych śladów — dowodów bożego istnienia. Jedyną odpowiedzią na słowa człowieka kierowane do Boga jest właściwie w poezji Barańczaka milczenie ${ }^{14}$. W opartym na paralelach wierszu Podnoszac z progu niedzielna gazetę $\mathrm{w}$ strofie ostatniej, w której podmiot zwraca się do Stwórcy, w miejsce poprzednich (kierowanych do mieszkańca Polski, a następnie człowieka zmarłego) rozkazów-próśb: „nie kłam” (W, s. 342), „nie fantazjuj” (W, s. 343), pojawia się: „tylko nie milcz” (W, s. 343). Wskazuje to, że milczenie jest spodziewaną (i od razu odżegnywaną) ,reakcją" Boga. W wierszu Drogi kaciku porad nawet ewentualna mowa (odpowiedź) Boga okazuje się milczeniem: „NA WSZYSTKO ODPOWIEM, / CHOĆ NIE USŁYSZYSZ ANI SŁOWA” (W, s. 377). Znakiem mógłby być „TYLKO STUK / WŁASNEGO SERCA” (W, s. 377), a zatem sam człowiek - z wpisaną w siebie potrzebą kontaktu z Transcendencją. Ludzka świadomość, w której pojawia się wyobrażenie boskiego Ty, jawi się zatem jako jedyny dowód Jego istnienia.

Warto jednak zwrócić uwagę na pojawiający się w wierszu przypominający echo rym ,pustkowie” (W, s. 377) - „ODPOWIEM” (W, s. 377). Niesłyszalna odpowiedź byłaby tu odpowiedzią pustkowia, a zatem nie mową Boga (ten wszakże nie istniałby), lecz echem słów ludzkich. Motyw echa i odbicia ${ }^{15}$ pojawia się również w wierszu I tak. Utwór rozpoczyna się $\mathrm{w}$ taki sposób, jak gdyby stanowił ciąg rozumowania - jest odpowiedzią podmiotu na ewentualność, jaką jest nieistnienie Boga. Barańczakowy bohater wyznaje, że jeśli nawet nie istnieje Bóg, „to i tak” (W, s. 374) będzie udawał, że jest kimś obserwowanym przez „biegłego świadka” (W, s. 374).

Ów Świadek ma być zarówno Obserwatorem pilnie i precyzyjnie śledzącym pojedyncze istnienie - określany jest w wierszu za pomocą nazw nowoczesnych urządzeń szpiegujących jako „superczuły noktowizor” (W, s. 374) i „szpiegowski satelita” (W, s. 374), jak i Opiekunem istnienia, Kimś, kto chroni przed zagubieniem, rozjaśnia mroki życia ${ }^{16}$, „W każdym z moich zaćmień on znajdzie dość światła” (W, s. 374), „,noktowizor w mętnym/ mroku" (W, s. 374).

W wierszu określa się ludzkie życie jako pobyt, postój, pęd, moment, punkt, wskazując na jego tymczasowość i zmienność. Dzięki Boskiej Świadomości, w której przechowana jest pamięć o niepowtarzalnym życiu jednostki, zniwelowane zostaje to de-

${ }^{14}$ Zwraca na to uwage J. Kandziora, Obserwator zaświatów. O wierszach metafizycznych Stanistawa Barańczaka, W Drodze $1990 \mathrm{nr}$ 1, s. 99.

${ }^{15} \mathrm{O}$ motywie tym w tomie Widokówka z tego świata pisali m.in.: J. Dembińska-Pawelec, Światy możliwe w poezji Stanisława Barańczaka, Katowice 1999, s. 111-112; J. Kandziora, Obserwator zaświatów, s. 100.

${ }^{16}$ Por. uwagi J. Dembińskiej-Pawelec, Światy możliwe, s. 109, 110. 
moniczne działanie przemijającego czasu, który unieważnia wartość pojedynczego istnienia, gubiąc je w ogromie wszechświata i przestrzeni. Funkcja Opiekuna możliwa jest zatem wyłącznie dzięki spełnianiu roli Świadka śledzącego bieg życia. Bóg miałby być Świadomością scalającą chaotyczne losy jednostki w znaczącą całość, ocalającą indywidualne światoodczucie. Czuwałby zatem nad tym, co poszczególne, nadawał znaczenie przemijającemu „okruchowi bytu”. Istnienie Boga okazuje się ważne w jednostkowym planie życia każdego człowieka, bo rejestruje, zapamiętuje pojedyncze istnienie i z każdego pojedynczego losu czyni „środek świata”.

Taka forma kontaktu z Bogiem, która zanurza jednostkę w zbiorowości i polega na czczeniu Go, nie może spełniać tej funkcji. Stąd Barańczakowa niechęć do rytuałów jako zinstytucjonalizowanych form kultu odprawianych kolektywnie, ujednolicających, włączających ,ja” w bezosobową grupę ${ }^{17}$. Bóg Barańczaka to Bóg jednostki, a nie zbiorowości, Bóg sensu, istoty, znaczenia, a nie rytuału i powierzchownych form kultu. Barańczakowy człowiek pragnie również istnienia Ty, które umożliwiałoby mu ocalenie w chwili śmierci - w obrazie przedstawiającym metaforycznie ten moment ,siatkówka oka” (W, s. 374) ewokująca symboliczny obraz Boga (oko wewnątrz trójkąta), a także Bożą Opatrzność, staje się równocześnie „,ratunkową siatką”:

[...] ratunkowa siatka,
od której się odbiję, gdy bryłą kaleką
runę z trapezu ziemi ku widowni nieb
nade mną, rozpostarta czujnie i daleko
siatkówka oka [...]

(W, s. 374)

Myśl o Bogu łączyłaby się zatem w wierszu również z myślą o nieśmiertelności, przy czym głównym ,zadaniem”, jakie spełniać ma istnienie Ty, jest nadanie sensu życiu. Wiersz odkrywałby więc tę zależność między wiarą w nieśmiertelność a poczuciem sensowności istnienia, o której tak pisze Leszek Kołakowski:

Nieuniknione wygaśnięcie ludzkiej osobowości wydaje się nam ostateczną porażką bytu; w przeciwieństwie do biologicznego rozpadu organizmu nie należy do naturalnego porządku kosmosu, wręcz gwałci ten porządek. O porządku, skoro empirycznie jest on niedostępny, można mówić tylko wówczas, gdy contingentia rerum odniesie się do koniecznej, a zatem wiecznej rzeczywistości. [...] jeżeli nic nie pozostaje po ludzkim wysiłku, jeżeli tylko Bóg jest rzeczywisty, a świat, dochodząc do swych ostatecznych przeznaczeń, pozostawia swego stwórcę tej samej pustce, czy pełni, którą cieszył się on zawsze, to naprawdę nie jest ważne, czy ten tajemniczy Król istnieje. Nie o to przy tym chodzi, że samolubnie wymagamy niebiańskiej nagrody lub nieskończonego zadośćuczynienia za naszą skończoną nędzę, jak zwykli przekonywać krytycy religii, lecz o to, że jeśli nic nie przetrwa prócz Boga, to ludzki znój i cierpienie nawet Bogu nie przysparzają dobra czy bogactw, a ostatnim słowem Bytu jest bezkresna pustka. Jeśli bieg wszechświata i spraw ludzkich nie ma żadnego sensu odniesionego do wieczności, to nie ma sensu w ogóle ${ }^{18}$.

Ten, o którym w wierszu I tak mówi człowiek, nie jest określony żadną religijnie sankcjonowaną nazwą (nie pojawia się tu również słowo „Ty” — tak często używane w poezji Barańczaka określenie Boga), stosowane do Jego nazwania peryfrazy nie są

${ }^{17} \mathrm{Na}$ te cechy Barańczakowej poezji zwracali również uwagę m.in.: K. Biedrzycki, Świat poezji, s. 260-261; D. Pawelec, Poezja Stanisława Barańczaka, s. 166.

${ }^{18}$ L. Kołakowski, Jeśli Boga nie ma... Horror metaphysicus, tłum. T. Baszniak, M. Panufnik, Poznań 1999, s. 130-131. 
nawet pisane wielką literą. Jest to oczywiście uzasadnione wpisaną w wiersz koncepcją — przecież człowiek mówi tu nie o boskim Bycie, a o swojej potrzebie Jego istnienia. Znamienny jest pojawiający się w utworze motyw teatru życia (czy raczej: cyrku) istota ludzka jawi się jako skoczek wykonujący akrobacje na „trapezie ziemi” przed „widownią nieb”. Obraz ten należy odnieść do stwierdzenia: „i tak będę/ udawał sam przed sobą" (W, s. 374). Człowiek jest tu aktorem na pustej scenie, który odgrywa sam przed sobą - i dla siebie - istnienie Boga, żyje tak, jakby patrzył na niego z owej „widowni” boski Opiekun ${ }^{19}$. Na dnie „oka” (W, s. 374) znajduje się tylko odbicie człowieka, z przestrzeni „nieb” (W, s. 374) wraca zaś echo jego własnych słów. Tam, gdzie powinien znajdować się Bóg, istnieje tylko człowiek (jego obraz), ludzkie słowo, wyobrażenie o Nim. Okazywałoby się więc, że istota ludzka sama sobie świadkuje, a Bóg jest projekcją jej świadomości. Co wszakże nie zmienia człowieczego położenia w świecie, nie zniechęca do ponawiana kontaktu — słowa „A jeśli nawet nie” (W, s. 374) są przecież wieczne, są powtarzane „w kółko” (W, s. 374). Dzięki nim można się obronić przed „bezkresną pustką”, o której pisze Kołakowski. Dlatego w Tablicy z Macondo Barańczak nazywa Boga Absolutnym Punktem Odniesienia, który „choćby był [...] ty lk o h i p o st a z ą, [...] powstrzymuje nas od rozpadu" ${ }^{20}$ [podkr. — J.K.].

Znamienne, że to właśnie byt człowieka jawi się — w wierszu Żeby w kwestii tej nocy byta petna jasność - jako byt pewny i konieczny (mimo swej skończoności), przy czym podkreślona zostaje waga ludzkiej samoświadomości („wiem, że jestem”) ${ }^{21}$. Dopiero człowiecze istnienie konstytuuje istnienie Boga: „nie myśl, że nie jestem w stanie/ wierzyć, żeś jest. W to nie wierz: jestem" (W, s. 380). Istnienie boże jest niejako potencjalne, wtórne wobec istnienia ludzkiego. Można tutaj zatem dostrzec odwrócenie biblijnego porządku, w którym to Bóg jest „tym, który Jest”22. Ludzka świadomość, będąca warunkiem bożego istnienia (bo gotowa uwierzyć w Stwórcę, stworzyć Jego wyobrażenie, nawet jeżeli On nie istnieje), staje się równocześnie jakąś n a d ś w i a d o m o ś c i ą. Nadświadomość, chociaż rodząca się z sięgania w mrok, ze świadomości ciemnego Losu — pustki, śmierci i cierpienia, nie jest z nią tożsama. Stanowi w y k r o c z e n i e poza istnienie ograniczone czasem, zamknięte w cielesności — jest przeczuciem wieczności, nadaniem sensu indywidualnemu ,dzianiu się” każdego życia. W wierszu Żeby w kwestii tej nocy byta petna jasność o owej umiejętności mówi się za pomocą wyrażeń zaczerpniętych z prawa karnego, odnoszących się do popełnienia przestępstwa:

${ }^{19}$ Joanna Dembińska-Pawelec słusznie pisze w tym kontekście o słynnym zakładzie Pascala; J. Dembińska-Pawelec, Światy możliwe, s. 114-115.

${ }^{20}$ S. Barańczak, Tablica z Macondo albo Najkrótsza poetyka normatywna na użytek wtasny, w sześsiu literach bez znaków diakrytycznych, z dygresjami motoryzacyjno-metafizycznymi, [w:] tegoż, Tablica z Macondo. Osiemnaście prób wyttumaczenia, po co i dlaczego się pisze, Londyn 1990, s. 232.

${ }^{21}$ Słowo ,jestem" (W, s. 380), powracające w zakończeniu każdej strofy, to łącznik w orzeczeniu w zdaniach, w których mówi się o ograniczeniach ludzkiego istnienia; zob.: M. Stala, Jasność nocy. Wokót jednego wiersza Stanisława Barańczaka, Znak $1997 \mathrm{nr}$ 9, s. 95. Marian Stala zwraca uwagę na to, że przez wyodrębnienie słowa ,jestem" w klauzuli Barańczak wydobywa pierwotne znaczenie owego wyrazu. „Jestem” w wierszu poety staje się niezwykle silnym stwierdzeniem przez podmiot faktu jednostkowego istnienia, jego afirmacją; zob.: tamże.

${ }^{22} \mathrm{~W}$ wierszu dokonywałoby się zatem odwrócenie poglądu zwolenników ontologicznego dowodu na istnienie Boga, zgodnie z którym wszelkie obiekty (także człowiek) mogą nie istnieć, a jedynie „Bóg nie może nie istnieć, jego istnienie jest konieczne, bo zawiera się w jego istocie”; W. Herman, Filozofia egzystencjalna, Warszawa 2001, s. 6. 


$$
\begin{aligned}
& \text { zdolność sięgania po kryjomu, } \\
& \text { na oślep, w zaczajony na nas } \\
& \text { mrok, umiejętność popełniania } \\
& \text { wykroczeń poza siebie, przestępstw } \\
& \text { przez kordon czaszki, zbrodni trwania } \\
& \text { większych niż śmierć [...] } \\
& \text { (W, s. 380) }
\end{aligned}
$$

Pojawiający się w wierszach Barańczaka motyw echa, własnego słowa człowieka zamiast spodziewanego głosu bożego (czyli: projekcji ludzkiej świadomości zamiast realnego istnienia Boga) nasuwa skojarzenie z Leśmianowską Dziewczyną ${ }^{23}$, w której głos słyszany zza muru przez braci i przypisywany przez nich dziewczynie okazuje się ułudą. W wierszu Leśmiana poza murem znajduje się nicość — próżnia i cisza. Ów głos okazuje się zatem głosem wewnętrznym człowieka - żywionym przez istoty ludzkie pragnieniem Dobra, Piękna, Boga, które każe im stwarzać wyobrażenie Czegoś Więcej i dążyć do odnalezienia Tego. Jednym z możliwych odczytań Dziewczyny jest i takie, że - mimo klęski, jaką odnosi człowiek, nie realizując w świecie swego pragnienia - sam wysiłek poszukiwania może nadać sens ludzkiemu życiu.

Myśl tę odnajdujemy również w twórczości Barańczaka — w wierszu Jakieś Ty własny głos człowieka, powracający doń jako echo, jest potwierdzeniem prawdy o ludzkim umieraniu i samotności we wszechświecie ${ }^{24}$ : ,jak bumerang/ ze świstem nadlatuje ciągle to samo pytanie/ zmienione w tę samą odpowiedź: że w międzyczasie umieram" (W, s. 347). Mimo to dokonuje się tu pogodzenie człowieka z niepoznawalnością, jak również możliwością nieistnienia Boga, z zastąpieniem Jego bytu przez ludzkie słowo o Nim:

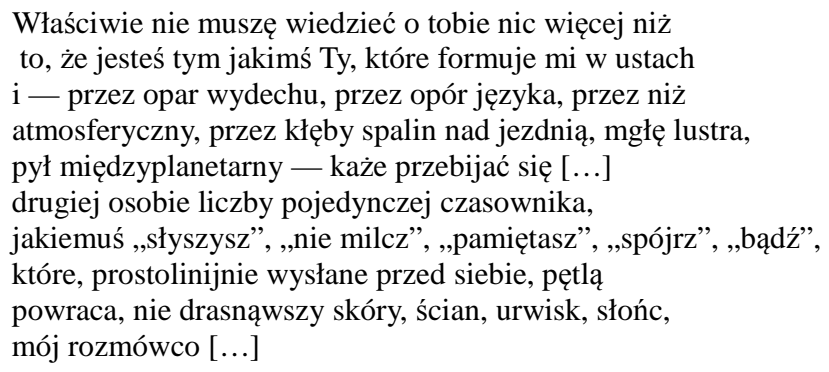

(W, s. 347)

Uznana zostaje bowiem wartość i ważność samego aktu powoływania w świadomości owego Ty do istnienia przez kierowanie Doń pytań ${ }^{25}$. Pytania te — na co zwraca

\footnotetext{
${ }^{23}$ Skojarzenie to jest dodatkowo uprawomocnione tym, że w Podróży zimowej Barańczak jawnie nawiązuje do wiersza Leśmiana, zamieszczając w pieśni $X$ następujące cytaty: „«I była zgroza nagłych cisz...»” (PZ, s. 399), ,«A ty z tej próżni czemu drwisz...»” (PZ, s. 399). Nawiązaniem do ostatnich zdań wiersza Leśmiana zdają się być także słowa kończące utwór Elegia trzecia, noworoczna: „Daleka gwiazda świeci/ bez żalu, bez pogardy/ ponad głowami” (T, s. 246).

${ }^{24}$ Por. uwagi J. Kandziory, Obserwator zaświatów, s. 100.

${ }^{25}$ Piotr Michałowski, analizując wiersz, pisze: „Bóg Barańczaka jest zaledwie dynamiczną hipotezą, która początkowo rodzi się tylko w języku i wypowiedzi — jako druga osoba narzucona przez gramatykę i reguły aktu komunikacji; dopiero potem zyskuje status ontologiczny. Z każdym wersem obserwujemy jak «słowo staje się ciałem», choć efemerycznym i zmiennym"; P. Michałowski, Adresat pilnie poszukiwany, Topos $2008 \mathrm{nr}$ 1-2, s. 80. W wierszu obserwujemy
} 
uwagę Piotr Michałowski - mają wyłącznie funkcję fatyczną, a zatem nie są przekazem informacji, lecz jedynie słowami, których celem jest ustanowienie kontaktu ${ }^{26}$.

Człowiekowi w poezji Barańczaka wystarczy samo wyobrażenie Boga — zgadywanego Rozmówcy, Świadka do którego można mówić o własnym istnieniu, wystarczy sama niepewność i przeczucie Tajemnicy — która pobudza do stawiania pytań i nawiązywania dialogu. Ustanawianie kontaktu jest bowiem powoływaniem przez ludzką świadomość boskiej perspektywy oglądu życia, umożliwia refleksyjne przeżywanie istnienia. Dialog — choć pozorny i jednostronny - pozwala na budowanie owej boskiej perspektywy scalającej i jako taki jest wartością — chociaż nie zmienia prawideł ciemnego Losu, to jednak nadaje znaczenie każdemu pojedynczemu losowi.

\section{GOD IN THE POETRY OF STANISŁAW BARAŃCZAK-THE DIRECTOR OF FATE AND WITNESS OF EXISTENCE}

The Author carries out analytical estimation of individual literary demonstrations of Barańczak, approaching late lyrics of the author of Atlantis. She writes as much about God as about human being (in his temporariness of existence) in that poetry, however it is a question of God's place in human world (fate's director and existence witness), problem of evil (human feeling of evil—God's knowledge about it; a motif of evil God, topos of empty heaven etc.) among other that become an object of interest.

KEY WORDS: S. Barańczak; Polish poetry; God in poetry.

(m.sz.)

także przejście „od Boga transcendentnego do Boga odnalezionego w sobie jako zwierciadła dla Ja”; tamże. Marian Stala, odczytując tom Widokówka z tego świata, pisze zaś: „Myśli o ciele i świecie odsłaniają nadrzędny i najtrudniejszy do dyskursywnego ujęcia problem tomu Barańczaka. Jest nim poszukiwanie Drugiej Osoby. Kogoś, kto potrafiłby napełnić sensem niejasne pismo tego świata. Kogoś, kto mógłby wziąć odpowiedzialność za jego porządek, kto by ten porządek uzasadnił... Albo: kogoś, kto by otworzył perspektywę innego świata. Kim jest ta Druga Osoba? [...] odpowiedź jest tajemnicą"; M. Stala, Między tym światem, s. 191.

${ }^{26}$ Zob.: P. Michałowski, Adresat pilnie, s. 74. 